\title{
The Effects of Korean Language Teachers' Job Satisfaction, Job Stress, Emotional Labor, and Psychological Burnout on Turnover Intention
}

\section{한국어교원의 직무만족도, 스트레스, 감정노동, 심리적 소진이 이직 의도에 미치는 영향}

\author{
Jiwon Yoon ${ }^{1}$, Meera Park ${ }^{2}$, Nam Joo Je ${ }^{3}$ \\ 윤지원 ${ }^{1}$, 박미라 ${ }^{2}$, 제남주 ${ }^{3}$ \\ ${ }^{1}$ Assistant Professor, Department of Korean Language Education, Changshin University, Korea, \\ jwyoon@cs.ac.kr \\ ${ }^{2}$ Assistant Professor, Department of nursing, Changshin University, Korea, minerva32@cs.ac.kr \\ ${ }^{3}$ Associate Professor, Department of nursing, Changshin University, Korea, jnj4757@cs.ac.kr
}

Corresponding author: Nam Joo Je

\begin{abstract}
The study attempted to determine factors that affect Korean language teachers' turnover intentions. For Korean language teachers working in Korea, targets were recruited through SNS, e-mail, and recruitment announcements, and out of the collected data, 118 were analyzed. The IBM SPSS WIN/25.0 was used which includes t-test, ANOVA, Pearson correlation coefficient, and multiple regression. The results of the study revealed that Job satisfaction was inversely correlated with job stress, psychological exhaustion, and turnover intention. Job stress had a positive correlation with emotional labor, psychological exhaustion, and turnover intention. Turnover intention was inversely correlated with job satisfaction and there is a positive correlation with job stress and psychological exhaustion. The factors that mostly influence the targets' intention to turnover intentions are job stress, after that, job satisfaction was followed by '30-39 years old'. The explanatory power of the model was $41.5 \%$. It is necessary to provide a program that can lower job stress and increase job satisfaction in order to lower the intention to turnover of Korean language teachers and it is also necessary to prepare a policy that can reduce turnover intentions in the age range, which had a high impact on turnover intention. The results of the study is intended to provide basic data for policy preparation that will help reduce the intention to turnover intentions of Korean language teachers.
\end{abstract}

Keywords: Korean Language Teacher, Job Satisfaction, Job Stress, Emotional Labor, Psychological Burnout, Turnover Intention

요약: 본 연구는 국내 한국어교원의 이직 의도에 미치는 영향을 파악하고자 시도되었다. 전국의 한국어교원을 대상으로 SNS와 메일, 모집공고문 등을 통해 대상자를 모집하여 수집된 118 부의 자료를 분석하였다. IBM SPSS WIN/25.0을 이용하여 t-test, ANOVA, Pearson correlation coefficient, Multiple regression을 사용하였다. 직무만족도는 직무스트레스, 심리적 소진, 이직 의도와 역상관관계가 있었다. 직무스트레스는 감정노동, 심리적 소진, 이직 의도와 
순상관관계가 있었다. 이직 의도는 직무만족도와 역상관관계가 있었고, 직무스트레스, 심리적 소진과 순상관관계가 있다. 대상자의 이직 의도에 가장 영향을 미치는 요인은 직무스트레스, 그 다음으로 직무만족도, '30-39세(연령)' 순이었으며 모형에 대한 설명력은 $41.5 \%$ 였다. 한국어교원의 이직 의도를 줄이기 위해서 직무스트레스를 낮춰주고 직무만족도를 높여줄 수 있는 프로그램 제공이 필요하며 이직 의도에 영향이 높았던 연령 구간의 이직 의도를 줄여 줄 수 있는 정책 마련도 필요하다. 본 연구의 결과는 한국어교원의 이직 의도 감소에 도움이 되는 정책 마련의 기초자료로 활용될 것으로 기대한다.

핵심어: 한국어교원, 직무만족도, 직무스트레스, 감정노동, 심리적 소진, 이직 의도

\section{1. 서론}

\section{1 연구의 필요성}

국립국어원 국어기본법에 따르면, 재외 동포나 외국인을 대상으로 국어를 가르치는 사 람을 '한국어교원'이라 한다. 이들은 실제 현장에서 한국어 교사, 한국어 선생님 등의 명 칭으로 불리지만, 본 연구에서는 자격증 명칭인 '한국어교원'으로 칭할 것이다. '한국어교 원 자격증 발급 현황'에 따르면 2005년 한국어교원 자격 제도 시행 이후 2021년 4월 기 준 58,563 명의 자격증 취득자가 배출되었다[1]. 이처럼 매년 한국어교원의 수는 급증하고 있지만, 이들의 처우 및 고충과 관련하여 크게 논의되지 못하였다. 선행연구에서도 한국 어 교사에 대한 위상과 처우는 미흡하며 특히 직무 불안정과 보상 부적절에서 높은 스트 레스를 보인다고 보고한 바 있으나[2] 여전히 처우는 나아지지 않았다.

직무스트레스는 직무와 관련하여 개인의 신체적, 정신적 건강에 해를 끼칠 뿐만 아니 라 조직에서는 직무만족을 감소시키고 업무의 질과 효율성을 떨어뜨린다[3]. 반복적으로 직무스트레스를 경험하면 신체·정신·정서적 소진 상태에 이르게 되는데, 이러한 소진은 부정적 자아개념과 부정적 업무태도를 갖게 하여 업무의 생산성을 낮추고, 직업에 대한 불만을 유발시켜 직장소속감을 떨어뜨려 결국 회사를 떠나게 되는 원인이 된다[4]. 직무 스트레스와 직무만족도, 심리적 소진, 이직 의도 등을 연관지어 살펴보는 것도 이러한 이 유 때문이다.

교사는 다른 직종과는 달리 직무적 특수성 때문에 높은 스트레스를 경험할 수밖에 없 고[5] 이는 개인의 신체적·심리적·행동적 측면에 부정적 영향을 미친다[6]. 이는 한국어교 원도 예외가 아니다. 한국어교원은 국내·외 한국어를 배우려는 외국인 학습자들에게 한국 어뿐만 아니라 한국 문화와 역사까지 체계적으로 가르치면서 그들에게 인지적, 정서적 영향을 미치게 된다. 또한, 한국어교육의 질을 좌우하고, 나아가 한국어교육의 성패를 판 가름하는 데 아주 중요한 역할을 하고 있다[7]. 이에 대다수의 한국어교원은 한국어 및 한국문화 전도사라는 높은 자부심을 갖지만, 낮은 보수 및 위상으로 인해 자존감의 감소 를 경험하는 직업으로 한국어교원이 느끼는 심리적 상태에 대한 연구는 꼭 필요하다. 국 외의 언어 교사와 관련된 연구에서도 $\mathrm{EFL}$ 교사의 자신감과 스트레스 사이의 관계[8], ELL 교사의 업무 스트레스에 영향을 미치는 요인[9], 교사의 자기효능감과 번아웃 감정[10], 외국어 교사의 감정노동 등에 대한 연구[11] 등이 활발히 진행 중이다. 국내에서는 초·중 등 교육을 비롯한 타 교육 분야의 교사 요인 관련 연구가 지속적으로 축적되어 오고 있 는데 반하여 한국어교원에 관한 연구는 많지 않다. 특히, 교사가 직무를 수행하는 과정 
중 필연적으로 겪게 되는 스트레스 등에 관한 연구는 분야별로 다양한 변인과 함께 이루 어지고 있으나, 한국어교원의 스트레스 등과 관련된 부정적 요인 관련 연구는 그 수가 훨씬 적은 편이라고 할 수 있다.

한국어교원의 직무스트레스 및 직무만족도 등과 관련 연구는 직무스트레스 요인[2][12], 직무스트레스와 교사효능감[13], 자기효능감과 직무만족도[14], 직무환경과 직무만족도[7] 등을 다룬 연구가 있다. 최근에는 COVID-19로 인한 비대면 수업 환경에서 한국어교원이 인식하는 직무스트레스 관련 연구[15]도 이루어졌으나 직무스트레스와 관련 깊은 감정노 동, 심리적 소진, 이직 의도 등을 함께 다룬 연구는 찾아볼 수 없었다. 교사의 직무스트 레스, 감정노동, 심리적 소진 등 부정적 요인을 제거하여 직무만족도가 높아지면, 그만큼 질 높은 수업을 할 수 있게 될 것이다. 그러므로 교사의 직무스트레스, 직무만족도, 심리 적 소진 등에 대한 지속적인 관심과 연구가 이루어져야 할 필요성이 제기된다. 한국어교 원의 직무 실태, 직무만족 등에 관한 논의는 현재 한국어교육 상황을 바로 보게 하며 이 러한 논의들은 현 상황을 개선할 수 있는 구체적 방안과 정책 도출에 도움이 되고, 나아 가 한국어교육의 질적 발전을 도모할 수 있게 해 줄 것이다[7].

이에 본 연구는 한국어교원을 대상으로 직무만족도, 직무스트레스, 감정노동, 심리적 소진이 이직 의도에 미치는 영향을 파악하여 근무환경 개선을 위한 기초자료를 제공하고 자 한다.

\section{2 연구목적}

본 연구의 목적은 한국어교원을 대상으로 직무만족도, 직무스트레스, 감정노동, 심리적 소진이 이직 의도에 미치는 영향을 파악하기 위함이며 구체적인 목적은 다음과 같다.

1) 대상자의 일반적 특성을 파악한다.

2) 대상자의 직무만족도, 직무스트레스, 감정노동, 심리적 소진, 이직 의도를 파악한 다.

3) 대상자의 일반적 특성에 따른 직무만족도, 직무스트레스, 감정노동, 심리적 소진, 이직 의도의 차이를 파악한다.

4) 각 변수 간의 상관관계를 파악한다.

5) 대상자의 이직 의도에 영향을 미치는 요인을 파악한다.

\section{2. 연구방법}

\section{1 연구설계}

본 연구는 대한민국에서 근무하는 한국어교원을 대상으로 직무만족도, 직무스트레스 감정노동, 심리적 소진, 이직 의도 정도와 변수들이 이직 의도에 미치는 영향을 파악하기 위한 서술적 조사 연구이다.

\section{2 연구대상 및 자료 수집}

연구 수행을 위하여 광고문으로 대상자를 모집하였다. 선정기준은 현재 기관에 소속되어 근무 중인 한국어교원 중 본 연구의 목적을 이해하고 참여에 동의한 교원이며 
현재 강의를 하지 않는 한국어교원은 제외하였다. $\mathrm{G}^{*}$ power 3.10 프로그램을 이용하여 회귀분석에서 효과 크기(effect size) .15(중간), 유의수준 $(\alpha) .05$, 검정력(1- $\beta$ ) .80, 변수 10 개로 산출한 결과, 적정표본 크기의 최소 인원은 118 명으로 산출되었으나 탈락률을 감안하여 120 명을 초기 대상으로 표집을 하였다. 자료 수집 기간은 2020년 12월 1일부터 2021년 1 월 15 일까지이며, 익명성과 편의성을 위해 온라인 구글(google) 설문으로 진행하였다. 먼저 SNS와 메일 등을 통해 대상자를 모집하고, 연구 참여에 동의한 대상자에게 연구 참여 동의서와 온라인 설문 링크를 발송하였다. 이 중 응답이 부실한 2 부를 제외한 118 명의 자료를 최종 분석에 사용하였다.

\section{3 연구 도구}

본 연구는 구조화된 설문지를 사용하였으며 일반적 특성과 직무만족도, 직무스트레스 감정노동, 심리적 소진, 이직 의도를 측정하는 92 문항으로 구성하였다.

\subsection{1 일반적 특성}

일반적 특성은 선행연구[12]에서 사용한 문항을 참조하여 연령, 성별, 지역, 현 직장경력, 시간당 수당, 지원동기의 총 6 문항으로 측정하였다.

\subsection{2 직무만족도}

직무만족도는 Jorde-Bloom (1989)이 제작한 유치원 직무만족 측정도구(ECJSS: Early Childhood Job Satisfaction Survey)에 ‘사회적 인식' 요인이 추가된 도구를 Hwang [14]이 최종 수정한 도구를 사용하여 측정하였다. 총 34 문항(직무 자체 6 문항, 근무환경·지원체계 7 문항, 보상체계 6 문항, 인간관계 8 문항, 기관 관계 2 문항, 사회적 인식 5 문항)으로 구성되어 있으며 5점 Likert 척도로 측정한다. 점수가 높을수록 직무만족도가 높은 것으로 해석한다. Hwang[14]의 연구에서의 신뢰도 Cronbach's $\alpha=.96$ 이었고, 본 연구에서 신뢰도 Cronbach's $\alpha=.91$ 이었다.

\subsection{3 직무스트레스}

직무스트레스는 Parker \& Decotiis (1983), Quinn \& Shepard (1974)의 연구를 근거로 Kang (2008)이 개발하고 $\operatorname{Lim}[16]$ 이 수정한 척도를 사용하였다. 직무스트레스 척도의 하위영역은 의기소침(6문항), 직무부담(6문항), 시간적 압박감(3문항) 3 가지로 구성되어 총 15 문항이다. 5점 Likert 척도로 점수가 높을수록 직무스트레스가 높음을 의미한다. $\operatorname{Lim}[16]$ 의 연구에서 신뢰도 Cronbach's $\alpha=.90$ 였고, 본 연구에서 신뢰도 Cronbach's $\alpha=.91$ 이었다.

\subsection{4 감정노동}

감정노동을 측정하기 위하여 Gilstrap (2005)의 연구를 근거로 Lee (2007)가 보육교사를 대상으로 사용한 설문지를 Seok[6]에서 중·고등학교 교사에 적합하도록 수정하여 사용한 것을 사용하였다. 감정노동 척도의 하위영역은 표면적 행동, 내면적 행동 2 가지로 총 10 문항으로 구성되어 있다. 5점 Likert 척도로 점수가 높을수록 감정노동이 심하다. Seok[6]의 연구에서 신뢰도 Cronbach's $\alpha=.87$ 이었고, 본 연구에서 신뢰도 Cronbach's $\alpha=.86$ 이었다. 


\subsection{5 심리적 소진}

심리적 소진은 Maslach와 Jackson (1981)이 개발한 Maslach Burnout Inventory (MBI) (1992)를 Kim (1995) 번안한 것을 Kang[17]이 초등학교 교사를 대상으로 사용한 설문지를 사용하여 측정하였다. 심리적 소진 척도는 총 22 문항으로 정서적 고갈, 비인격화, 성취감 저하 3 가지 하위요인으로 구성되어 있고 5점 Likert 척도로 점수가 높을수록 심리적 소진이 높음을 의미한다. $\mathrm{Kang}[17]$ 의 연구에서 신뢰도 Cronbach's $\alpha=.90$ 이었고, 본 연구에서 신뢰도 Cronbach's $\alpha=.91$ 이었다.

\subsection{6 이직 의도}

이직 의도는 Cook 등(1981)의 이직 의도 측정 문항을 정신보건 영역에 맞게 수정하여 사용한 Hwang[18]의 이직 의도 도구(총 5문항)를 이용하여 측정하였다. 이때, 2 번 문항 '나는 다른 정신보건 시설에서 처우만 개선해 준다면 이 기관을 떠날 수 있다'에서 정신보건 시설을 한국어교육원으로 수정하여 사용하였다. 5점 Likert 척도로 점수가 높을수록 이직 의도가 높음을 의미한다. Hwang[18]의 연구에서 신뢰도 Cronbach's $\alpha=.88$ 이상이었고, 본 연구에서 신뢰도 Cronbach's $\alpha=.87$ 이었다.

\section{4 윤리적 고려}

연구자는 먼저 연구목적, 진행 절차, 익명성 보장 등에 대한 설명으로 대상자의 자율성과 권익 보호를 설명하고, 연구 참여희망자에게 동의서를 받았다. 설문 소요 시간은 20 분 정도이며 설문에 대한 응답은 익명으로 처리되고 언제든지 도중에 연구 참여를 자유의사에 따라 포기할 수 있고, 중도 포기 시 불이익이 없다는 것을 설명하였다. 또한, 비밀과 익명이 보장됨을 설명하고 온라인 자료는 password가 있는 파일에 저장하여 연구자 외의 접근을 제한하고 설문지 파일은 연구종료 후 3 년 동안 보관한 후 삭제할 것이며 대상자의 개인정보와 조사 자료는 숫자화 하여 연구목적으로만 사용함을 설명하였다.

\section{5 자료 분석}

자료 분석은 IBM SPSS/25 통계프로그램을 이용하였고, 결과에 대한 유의수준은 .05로 측정하였다. 측정 도구의 신뢰도를 실시하였다. 대상자의 일반적 특성은 빈도(백분율), 각 변수는 평균과 표준편차를 구하였다. 대상자의 일반적 특성에 따른 직무만족도, 직무스트레스, 감정노동, 심리적 소진, 이직 의도의 차이는 t-rest, one-way ANOVA로 측정하였고, 변수들의 상관관계는 Pearson's correlation coefficient를 구하였으며, 이직 의도에 영향을 미치는 요인은 단계적 회귀분석(Stepwise regression)으로 구하였다.

\section{6 연구의 제한점}

본 연구는 COVID-19로 인한 특수한 사회적 상황에서 진행된 논문으로 신중한 해석과 주의가 필요하며 한국어교원 중 일부가 참여하였기 때문에 연구 결과를 확대하여 일반화함에 제한점이 있다. 


\section{3. 연구결과}

\section{1 대상자의 일반적 특성}

대상자의 일반적 특성을 살펴보면 연령은 ‘30세-39세'가 64명(54.2\%)으로 가장 많았다. 성별은 '여성' 104 명(88.1\%), '남성' 14 명 $(11.9 \%)$ 으로 여성이 대부분을 차지하였다. 지역은 ‘수도권'이 41명(34.7\%)으로 가장 많았고, 다음은 '충청권' 37명(31.4\%)이었다. 대상자 중 현 직장 경력은 ' 3 년 1 개월-10년'이 45 명 $(38.1 \%)$ 으로 가장 많았다. 시간당 보수는 ' 30,000 35,000 원'이 80 명 $(67.8 \%)$ 으로 가장 많았고, 지원 동기는 '한국어 교육에 대한 관심'이 82 명 $(69.5 \%)$ 으로 가장 많았다[Table 1].

[표 1] 대상자의 일반적 특성

[Table 1] Characteristics of Participants $(\mathrm{N}=118)$

\begin{tabular}{|c|c|c|}
\hline Characteristics & Categories & $\mathrm{n}(\%)$ \\
\hline \multirow{4}{*}{$\operatorname{Age}(y r)$} & $20-29$ & $8(6.8)$ \\
\hline & $30-39$ & $64(54.2)$ \\
\hline & $40-49$ & $36(30.5)$ \\
\hline & $\geq 50$ & $10(8.5)$ \\
\hline \multirow{2}{*}{ Gender } & Male & 14(11.9) \\
\hline & Female & 104(88.1) \\
\hline \multirow{4}{*}{ Area } & Seoul metropolitan area & $41(34.7)$ \\
\hline & Chungcheong area & $37(31.4)$ \\
\hline & Jeolla area & $6(5.1)$ \\
\hline & Gyeongsang area & $34(28.8)$ \\
\hline \multirow{4}{*}{$\begin{array}{l}\text { Career(yr) } \\
\text { (Current Workplace) }\end{array}$} & $\leq 1$ & $23(19.5)$ \\
\hline & $1.1-3$ & $32(27.1)$ \\
\hline & $3.1-10$ & $45(38.1)$ \\
\hline & $\geq 10.1$ & $18(15.3)$ \\
\hline \multirow{4}{*}{$\begin{array}{l}\text { Hourly pay } \\
\text { (Won) }\end{array}$} & $<30,000$ & $23(19.5)$ \\
\hline & $30,000-35,000$ & $80(67.8)$ \\
\hline & $36,000-39,000$ & $8(6.8)$ \\
\hline & $\geq 40,000$ & $7(5.9)$ \\
\hline \multirow{4}{*}{$\begin{array}{l}\text { Motivation for Korean } \\
\text { Language Teachers }\end{array}$} & Interested in Korean language education & $82(69.5)$ \\
\hline & Develop your own aptitude and talent & $23(19.5)$ \\
\hline & Encourage people around you & $7(5.9)$ \\
\hline & Economic help, etc. & $6(5.1)$ \\
\hline
\end{tabular}

\section{2 직무만족도, 직무스트레스, 감정노동, 심리적 소진, 이직 의도}

대상자의 직무만족도는 전체 평균 3.16점(5점 만점)이었고, 하위요인인 직무 자체는 4.16점으로 가장 높은 평균값을 나타냈으며 그 다음으로 인간관계 3.22점, 사회적 인식 3.08 점, 기관 관계 3.08 점, 근무환경·지원체계 2.97점, 사회적 인식 2.88점, 보상체계 2.59점 순으로 나타났다. 직무스트레스는 평균 3.25점(5점 만점), 감정노동은 평균 4.21점(5점 
만점), 심리적 소진은 평균 2.47점(5점 만점), 이직 의도는 평균 3.74 점(5점 만점)이었다[Table 2].

[표 2] 대상자의 직무만족도, 직무스트레스, 감정노동, 심리적 소진과 이직 의도

[Table 2] Subject's Job Satisfaction, Job Stress, Emotional Labor, Psychological Burnout, and Turnover Intention $(\mathrm{N}=118)$

\begin{tabular}{|c|c|c|c|}
\hline Variables & Mean \pm SD & Min & $\operatorname{Max}$ \\
\hline Job satisfaction & $3.16 \pm 0.54$ & 2.00 & 4.65 \\
\hline The job itself & $4.16 \pm 0.61$ & 2.50 & 5.00 \\
\hline Working environment resource system & $2.97 \pm 0.79$ & 1.14 & 5.00 \\
\hline Compensation system & $2.59 \pm 0.73$ & 1.00 & 4.33 \\
\hline Human relationship & $3.22 \pm 0.81$ & 1.38 & 5.00 \\
\hline Institutional relations & $3.08 \pm 1.03$ & 1.00 & 5.00 \\
\hline Social awareness & $2.88 \pm 0.79$ & 1.20 & 4.80 \\
\hline Job stress & $3.25 \pm 0.91$ & 1.27 & 4.87 \\
\hline Emotional labor & $4.21 \pm 0.59$ & 2.80 & 5.00 \\
\hline Psychological burnout & $2.47 \pm 0.75$ & 1.00 & 3.95 \\
\hline Turnover intention & $3.74 \pm 1.03$ & 1.00 & 5.00 \\
\hline
\end{tabular}

3.3 대상자의 일반적 특성에 따른 직무만족도, 직무스트레스, 감정노동, 심리적 소진, 이직 의도

대상자의 일반적 특성에 따른 직무만족도, 직무스트레스, 감정노동, 심리적 소진, 이직 의도의 결과는 다음과 같다[Table 3]. 먼저 대상자의 일반적 특성에 따른 직무만족도의 경 우, 연령에 따라 유의한 차이를 보였고 $(\mathrm{F}=4.54, p=.005)$, 사후검증 결과 ' 50 세 이상' 집단 이 '30-39세', '40-49세' 집단보다 직무만족도가 통계적으로 유의하게 높았다. 지역에 따라 유의한 차이를 보였고 $(\mathrm{F}=4.48, p=.005)$, 사후검증 결과, '수도권' 집단이 '충청권' 집단보다 직무만족도가 높았다. 시간당 보수에 따라 유의한 차이를 보였으나 $(\mathrm{F}=2.89, p=.038)$, 사후 검증 결과, 집단 간 유의한 차이는 없었다. 직무스트레스는 연령에 따라 유의한 차이를 보였으나 $(\mathrm{F}=2.95, p=.035)$. 사후검증 결과, 집단 간 유의한 차이는 없었다. 지역에 따라 유 의한 차이를 보였고 $(\mathrm{F}=4.48, p=.005)$, 사후검증 결과, '충청권' 집단이 '전라권' 집단보다 직 무스트레스가 높았다. 시간당 보수에 따라 유의한 차이를 보였으나 $(\mathrm{F}=3.62, p=.015)$, 사후 검증 결과 집단 간 유의한 차이는 없었다. 감정노동의 경우, 연령에 따라 유의한 차이를 보였으나 $(\mathrm{F}=2.71, p=.048)$, 사후검증 결과 집단 간 유의한 차이는 없었다. 심리적 소진의 경우, 연령에 따라 유의한 차이를 보였고 $(\mathrm{F}=4.47, p=.005)$. 사후검증 결과, '20-29세' 집단 이 '40-49세', ‘50이상' 집단보다 심리적 소진이 통계적으로 유의하게 높았다. 지역에 따라 유의한 차이를 보였고 $(\mathrm{F}=4.55, p=.005)$, 사후검증 결과, '충청권' 집단이 '전라권' 집단보다 심리적 소진이 높았다. 시간당 보수에 따라 유의한 차이를 보였고 $(\mathrm{F}=4.51, p=.005)$, 사후검 증 결과 ' 30,000 원 이하' 집단이 ' $36,000-39,000$ 원' 집단보다 심리적 소진이 높았다. 이직 의도의 경우, 연령에 따라 유의한 차이를 보였으나 $(\mathrm{F}=3.08, p=.030)$. 사후검증 결과 집단 간 유의한 차이가 없었다. 시간당 보수에 따라 유의한 차이를 보였고 $(\mathrm{F}=4.51, p=.005)$, 사 후검증 결과, ‘ 30,000 원 이하' 집단이 ‘ $36,000-39,000$ 원' 집단보다 이직 의도가 높았다. 
[표 3] 대상자의 일반적 특성에 따른 직무만족도, 직무스트레스, 감정노동, 심리적 소진과

$$
\text { 이직 의도 }
$$

[Table 3] Job Satisfaction, Job Stress, Emotional Labor, Psychological Burnout, and Turnover Intention acording to the General Characteristics of the Subject $(\mathrm{N}=118)$

\begin{tabular}{|c|c|c|c|c|c|c|c|c|c|c|c|}
\hline \multirow{2}{*}{ Characteristics } & \multirow{2}{*}{ Categories } & \multicolumn{2}{|c|}{ Job satisfaction } & \multicolumn{2}{|c|}{ Job stress } & \multicolumn{2}{|c|}{ Emotional labor } & \multicolumn{2}{|c|}{$\begin{array}{l}\text { Psychological } \\
\text { burnout }\end{array}$} & \multicolumn{2}{|c|}{$\begin{array}{l}\text { Turnover } \\
\text { intention }\end{array}$} \\
\hline & & $\mathrm{M} \pm \mathrm{SD}$ & $\begin{array}{l}\mathrm{t}(p) / \\
\mathrm{F}(p)\end{array}$ & $\mathrm{M} \pm \mathrm{SD}$ & $\begin{array}{l}\mathrm{t}(p) / \\
\mathrm{F}(p)\end{array}$ & $\mathrm{M} \pm \mathrm{SD}$ & $\begin{array}{l}\mathrm{t}(p) / \\
\mathrm{F}(p)\end{array}$ & $\mathrm{M} \pm \mathrm{SD}$ & $\begin{array}{l}\mathrm{t}(p) / \\
\mathrm{F}(p)\end{array}$ & $\mathrm{M} \pm \mathrm{SD}$ & $\begin{array}{l}\mathrm{t}(p) / \\
\mathrm{F}(p)\end{array}$ \\
\hline \multirow{4}{*}{ Age(yr) } & $20-29^{\mathrm{a}}$ & $3.15 \pm 0.41$ & \multirow{4}{*}{$\begin{array}{l}4.54 \\
(.005) \\
b, c<d\end{array}$} & $3.66 \pm 0.60$ & \multirow{4}{*}{$\begin{array}{c}2.95 \\
(.035)\end{array}$} & $4.37 \pm 0.65$ & \multirow{4}{*}{$\begin{array}{c}2.71 \\
(.048)\end{array}$} & $3.18 \pm 0.45$ & \multirow{4}{*}{$\begin{array}{c}4.47 \\
(.005) \\
a>c, d\end{array}$} & $4.05 \pm 0.97$ & \multirow{4}{*}{$\begin{array}{l}3.08 \\
(.030)\end{array}$} \\
\hline & $30-39^{b}$ & $3.13 \pm 0.44$ & & $3.35 \pm 0.89$ & & $4.28 \pm 0.55$ & & $2.51 \pm 0.71$ & & $3.95 \pm 0.84$ & \\
\hline & $40-49^{c}$ & $3.05 \pm 0.60$ & & $3.18 \pm 0.94$ & & $4.18 \pm 0.58$ & & $2.38 \pm 0.80$ & & $3.42 \pm 1.17$ & \\
\hline & $\geq 50^{\mathrm{d}}$ & $3.73 \pm 0.66$ & & $2.55 \pm 0.89$ & & $3.75 \pm 0.62$ & & $1.97 \pm 0.56$ & & $3.28 \pm 1.32$ & \\
\hline \multirow{2}{*}{ Gender } & Male & $3.06 \pm 0.36$ & \multirow{2}{*}{$\begin{array}{l}-0.69 \\
(.487)\end{array}$} & $3.14 \pm 0.63$ & \multirow{2}{*}{$\begin{array}{l}-0.50 \\
(.617)\end{array}$} & $4.11 \pm 0.54$ & \multirow{2}{*}{$\begin{array}{l}-0.68 \\
(.495)\end{array}$} & $2.46 \pm 0.71$ & \multirow{2}{*}{$\begin{array}{l}-0.03 \\
(.969)\end{array}$} & $4.12 \pm 0.68$ & \multirow{2}{*}{$\begin{array}{c}1.49 \\
(.136)\end{array}$} \\
\hline & Female & $3.17 \pm 0.56$ & & $3.27 \pm 0.94$ & & $4.22 \pm 0.59$ & & $2.47 \pm 0.76$ & & $3.68 \pm 1.06$ & \\
\hline \multirow{4}{*}{ Area } & $\begin{array}{c}\text { Seoul metropolitan } \\
\text { area }\end{array}$ & $3.31 \pm 0.56$ & \multirow{4}{*}{$\begin{array}{c}4.48 \\
(.005) \\
a>b\end{array}$} & $3.13 \pm 0.91$ & \multirow{4}{*}{$\begin{array}{c}5.11 \\
(.002) \\
b>c\end{array}$} & $4.26 \pm 0.58$ & \multirow{4}{*}{$\begin{array}{c}0.69 \\
(.560)\end{array}$} & $2.31 \pm 0.90$ & \multirow{4}{*}{$\begin{array}{c}4.55 \\
(.005) \\
b>c\end{array}$} & $3.63 \pm 1.08$ & \multirow{4}{*}{$\begin{array}{c}2.38 \\
(.073)\end{array}$} \\
\hline & Chungcheong area ${ }^{\mathrm{b}}$ & $2.92 \pm 0.38$ & & $3.65 \pm 0.74$ & & $4.27 \pm 0.53$ & & $2.69 \pm 0.56$ & & $4.07 \pm 0.83$ & \\
\hline & Jeolla area ${ }^{c}$ & $3.44 \pm 0.61$ & & $2.35 \pm 1.02$ & & $4.21 \pm 0.77$ & & $1.65 \pm 0.45$ & & $3.10 \pm 1.16$ & \\
\hline & ${\text { Gyeongsang } A r e a^{\mathrm{d}}}$ & $3.19 \pm 0.57$ & & $3.14 \pm 0.92$ & & $4.09 \pm 0.62$ & & $2.56 \pm 0.65$ & & $3.62 \pm 1.09$ & \\
\hline \multirow{4}{*}{$\begin{array}{l}\text { Career } \\
\text { (Current } \\
\text { Workplace) }\end{array}$} & $\leq 1$ & $3.04 \pm 0.30$ & \multirow{4}{*}{$\begin{array}{c}0.77 \\
(.511)\end{array}$} & $3.37 \pm 0.90$ & \multirow{4}{*}{$\begin{array}{l}0.16 \\
(.920)\end{array}$} & $4.40 \pm 0.54$ & & $2.32 \pm 0.71$ & \multirow{4}{*}{$\begin{array}{l}0.83 \\
(.475)\end{array}$} & $3.59 \pm 0.82$ & \multirow{4}{*}{$\begin{array}{c}1.06 \\
(.365)\end{array}$} \\
\hline & $1.1-3$ & $3.20 \pm 0.64$ & & $3.20 \pm 0.93$ & & $4.14 \pm 0.71$ & $\begin{array}{l}1.70 \\
(.169)\end{array}$ & $2.43 \pm 0.88$ & & $3.77 \pm 1.09$ & \\
\hline & $3.1-10$ & $3.22 \pm 0.45$ & & $3.23 \pm 0.86$ & & $4.11 \pm 0.55$ & & $2.60 \pm 0.61$ & & $3.91 \pm 0.94$ & \\
\hline & $\geq 10.1$ & $3.08 \pm 0.75$ & & $3.27 \pm 1.09$ & & $4.34 \pm 0.44$ & & $2.41 \pm 0.86$ & & $3.44 \pm 1.35$ & \\
\hline \multirow{4}{*}{$\begin{array}{l}\text { Hourly pay } \\
\text { (Won) }\end{array}$} & $<30,000^{\mathrm{a}}$ & $3.12 \pm 0.42$ & & $3.34 \pm 0.95$ & & $4.23 \pm 0.52$ & & $2.74 \pm 0.75$ & & $3.97 \pm 0.98$ & \\
\hline & $30,000-35,000^{\mathrm{b}}$ & $3.10 \pm 0.52$ & $\begin{array}{c}2.89 \\
(.038)\end{array}$ & $3.36 \pm 0.87$ & $\begin{array}{c}3.62 \\
(.015)\end{array}$ & $4.20 \pm 0.58$ & $\begin{array}{c}0.69 \\
(.556)\end{array}$ & $2.50 \pm 0.72$ & $\begin{array}{c}4.51 \\
(.005)\end{array}$ & $3.78 \pm 0.95$ & $\begin{array}{l}3.15 \\
(.027)\end{array}$ \\
\hline & $36,000-39,000^{\mathrm{c}}$ & $3.59 \pm 0.70$ & & $2.50 \pm 0.83$ & & $4.45 \pm 0.52$ & & $1.85 \pm 0.73$ & $a>c$ & $2.72 \pm 1.40$ & $a>c$ \\
\hline & $\geq 40,000^{\mathrm{d}}$ & $3.46 \pm 0.70$ & & $2.61 \pm 0.84$ & & $4.01 \pm 0.95$ & & $1.91 \pm 0.58$ & & $3.68 \pm 1.23$ & \\
\hline & $\begin{array}{l}\text { Interested in Korean } \\
\text { language education }\end{array}$ & $3.15 \pm 0.48$ & & $3.36 \pm 0.93$ & & $4.26 \pm 0.57$ & & $2.50 \pm 0.75$ & & $3.70 \pm 0.95$ & \\
\hline $\begin{array}{l}\text { Motivation for } \\
\text { Korean }\end{array}$ & $\begin{array}{l}\text { Develop your own } \\
\text { aptitude and talent }\end{array}$ & $3.27 \pm 0.63$ & $\begin{array}{c}1.72 \\
(.164)\end{array}$ & $3.00 \pm 0.86$ & $\begin{array}{c}1.15 \\
(.329)\end{array}$ & $4.00 \pm 0.69$ & $\begin{array}{c}1.18 \\
(.319)\end{array}$ & $2.21 \pm 0.61$ & $\begin{array}{l}1.67 \\
(.175)\end{array}$ & $4.00 \pm 1.10$ & $\begin{array}{l}1.95 \\
(.124)\end{array}$ \\
\hline $\begin{array}{l}\text { Language } \\
\text { Teachers }\end{array}$ & $\begin{array}{l}\text { Encourage people } \\
\text { around you }\end{array}$ & $2.76 \pm 0.32$ & & $3.13 \pm 0.76$ & & $4.28 \pm 0.36$ & & $2.86 \pm 0.77$ & & $4.02 \pm 1.00$ & \\
\hline & Economic help, etc. & $3.30 \pm 0.90$ & & $2.97 \pm 0.94$ & & $4.25 \pm 0.50$ & & $2.62 \pm 1.05$ & & $2.93 \pm 1.58$ & \\
\hline
\end{tabular}

\section{4 직무만족도, 직무스트레스, 감정노동, 심리적 소진과 이직 의도의 상관관계}

직무만족도는 직무스트레스 $(\mathrm{r}=-.46, p<.001)$, 심리적 소진 $(\mathrm{r}=-.47, p<.001)$, 이직 의도 $(\mathrm{r}=-.48, p<.001)$ 와 역상관관계가 있었다. 직무스트레스는 감정노동 $(\mathrm{r}=.21, p=.023)$, 심리적 소진 $(\mathrm{r}=.75, p<.001), \quad$ 이직 의도 $(\mathrm{r}=.59, p<.001)$ 와 순상관관계가 있었다. 이직 의도는 직무만족도 $(\mathrm{r}=-.48, p<.001)$ 와 역상관관계가 있었고, 직무스트레스 $(\mathrm{r}=.59, p<.001)$, 심리적 소진( $\mathrm{r}=.45, p<.001)$ 과 순상관관계가 있다[Table 4]. 
[표 4] 직무만족도, 직무스트레스, 감정노동, 심리적 소진과 이직 의도의 상관관계

[Table 4] Correlation between Job Satisfaction, Job Stress, Emotional Labor, Psychological Burnout, and Turnover Intention $(\mathrm{N}=118)$

\begin{tabular}{|c|c|c|c|c|c|}
\hline & Job satisfaction & Job stress & Emotional labor & $\begin{array}{c}\text { Psychological } \\
\text { burnout }\end{array}$ & $\begin{array}{l}\text { Turnover } \\
\text { intention }\end{array}$ \\
\hline & \multicolumn{5}{|c|}{$\mathrm{r}(p)$} \\
\hline Job satisfaction & 1 & & & & \\
\hline Job stress & $\begin{array}{c}-.46 \\
(<.001)\end{array}$ & 1 & & & \\
\hline Emotional labor & $\begin{array}{c}.078 \\
(.402)\end{array}$ & $\begin{array}{c}.21 \\
(.023)\end{array}$ & 1 & & \\
\hline Psychological burnout & $\begin{array}{c}-.47 \\
(<.001)\end{array}$ & $\begin{array}{c}.75 \\
(<.001)\end{array}$ & $\begin{array}{c}.01 \\
(.845)\end{array}$ & 1 & \\
\hline Turnover intention & $\begin{array}{c}-.48 \\
(<.001)\end{array}$ & $\begin{array}{c}.59 \\
(<.001)\end{array}$ & $\begin{array}{c}.07 \\
(.403)\end{array}$ & $\begin{array}{c}.45 \\
(<.001)\end{array}$ & 1 \\
\hline
\end{tabular}

\section{5 이직 의도에 영향을 미치는 요인}

대상자의 이직 의도에 영향을 미치는 요인을 확인하기 위해 이직 의도와 상관관계가 있었던 연령, 시간당 보수, 직무만족도, 직무스트레스, 심리적 소진을 독립변수로 투입하였다. 연령, 시간당 보수는 더미변수 처리하였다. 단계적 입력(Stepwise) 방식으로 Multiple regression analysis를 실시하였다. 다중공선성 문제를 검정하기 위해 공차 한계가 0.1이상 되는지 확인한 결과, 공차한계 .40-.97로 다중공선성의 문제가 없었고, 분산팽창계수 VIF (Variance Inflation Factor) 10 이상을 넘지 않는지 확인한 결과, VIF 1.022.46 으로 다중 공선성의 문제가 없었다. 또한 잔차의 자기상관성에 문제가 없는 것으로 확인하기 위해 잔차의 독립성 검정인 Durbin-Watson Test로 확인 한 결과 $\mathrm{d}=2.292$ 으로 수용기준에 부합하였다. 대상자의 이직 의도에 가장 영향을 미치는 요인은 직무스트레스 $(\beta=.483, \mathrm{p}<.001), \quad$ 그 다음으로 직무만족도 $(\beta=-.259, \mathrm{p}=.002), \quad$ 연령‘3039 세' $(\beta=.148, \mathrm{p}=.041)$ 순이었다. 모형에 대한 설명력은 $41.5 \%$ 였다 $(\mathrm{F}=17.59, \mathrm{p}<.001)$ [Table 5].

\section{[표 5] 이직 의도에 대한 다중회귀분석}

[Table 5] Multiple Regression Analysis on Turnover Intention ( $\mathrm{N}=118)$

\begin{tabular}{|l|c|c|c|c|c|}
\hline & $\mathrm{B}$ & $\mathrm{SE}$ & $\beta$ & $\mathrm{t}$ & $p$ \\
\hline (Constant) & 3.625 & .705 & & 5.13 & $<.001$ \\
\hline ‘36,000-39,000’Hourly pay (won)* & -0.422 & .302 & -.103 & -1.39 & .165 \\
\hline ‘30-39’ Age(yr)* & 0.307 & .148 & .148 & 2.07 & .041 \\
\hline Job satisfaction & -0.496 & .157 & -.259 & -3.16 & .002 \\
\hline Job stress & 0.546 & .125 & .483 & 4.35 & $<.001$ \\
\hline Psychological burnout & -0.094 & .153 & -.068 & -.616 & .539 \\
\hline \multicolumn{2}{|l|}{$\mathrm{R}^{2}=.440, \mathrm{Adj} \mathrm{R}^{2}=.415, \mathrm{~F}=17.59 p<.001$} & & \\
\hline
\end{tabular}

*Dummy variable 


\section{4. 논의}

본 연구는 국내 한국어교원을 대상으로 이직 의도에 미치는 영향요인을 확인하기 위한 서술적 조사연구이다. 연구 결과를 토대로 다음과 같이 논의하고자 한다.

본 연구에서 한국어교원의 직무만족도는 평균 3.16점(5점 만점)으로 직무만족도의 하위요인인 직무 자체가 가장 높았고(4.16점), 보상체계가 가장 낮게 나타났는데(2.59점), 이는 같은 도구로 전북의 한국어교육지도사를 대상으로 한 선행연구[14]와 유사한 결과이다. 그러나 선행연구[14]에서는 직무만족도가 평균 4.09점으로 본 연구결과보다 높았다. 이는 본 연구가 지역을 특정하지 않고 전국의 대상자를 모집하였기에 차이가 있는 것으로 생각된다. 본 연구에서도 전라 지역의 직무만족도가 다른 지역에 비해 높게 나타나(3.44점) 지역마다 한국어교원에 대한 처우와 교육 현장이 다름을 입증하는 결과로 보았다. 전국적으로 한국어교원이 느끼는 직무만족도는 낮으므로 이는 추후 반복 연구를 통해 재확인할 필요가 있다. 또한 도구는 달라 직접적인 비교는 힘들지만 직업에 대한 만족은 높은 반면 직무만족도는 낮고, 복지와 보수에 대한 만족이 매우 낮게 나타난 연구[7]와 한국어교원의 대부분이 자신의 시급에 대해 불만족을 보인다고 보고한 연구[14] 결과와도 유사한 결과라 할 수 있다. Lee의 연구[19]에서도 한국어교원은 처우나 교육 환경적인 부분보다 가르치는 활동에서 자부심을 느끼고, 학습자의 긍정적 변화 과정에서 오는 보람과 뿌듯함, 직무 그 자체로 만족하고 있었으며, 과중한 업무와 평가 스트레스, 직업으로서의 불안정한 현실 등으로 불만족을 느끼고 있었다.

한국어교원이 인지하는 직무스트레스는 평균 3.25점(5점 만점)으로 나타나 한국어교원의 직무스트레스가 높다고 보고한 선행연구[2]를 뒷받침해 준다. 이는 선행연구[2][12]에서 보고한 것과 같이 한국어교원은 낮은 직위와 짧은 계약 단위 등으로 직업이 안정적이지 않고, 시간당 보수는 낮으면서 담당 학생 수는 많아 일로 인해 받는 보상이 기대치보다 낮았기 때문으로 생각된다. 한국어교육기관에서 한국어교원이 받는 시간당 강의료가 10 년이 넘도록 변화가 없어 실제로 한국어교원이 받는 처우가 불안정적임을 주장하는 결과[19]와도 일맥상통한다. 게다가 본 연구의 설문조사 진행 당시 COVID-19로 인해 대면 수업이 어려워지면서 갑자기 비대면 수업으로 전환되었고, 기관의 상황에 따라 한국어 수업이 없어져 수업을 하지 못하게 된 교원들도 생겨났다. 이러한 상황으로 미루어 보았을 때, 비대면 수업환경에서의 수업 준비와 학생과의 의사소통 및 상호작용, 학생 관리의 어려움 등이 직무스트레스를 가중시켰을 것으로 볼 수 있다[15]. 또한, 직무스트레스는 지역에 따라 유의한 차이를 보였는데 Sim과 Jung의 연구[2]에서 대구.경북에서 근무하는 한국어교원이 서울에서 근무하는 한국어교원에 비해 직무스트레스가 높다고 보고한 결과와 유사하다. 이 역시 지역에 따라 근무환경과 복지 및 보수에 차이가 있음을 보여주는 결과이다.

심리적 소진은 연령에 따라 유의한 차이를 보였고, 사후검증 결과 '20-29세' 집단이 '30-39세', '40-49세' 집단보다 심리적 소진이 높았다. 중·고등학교 교사 대상의 연구[6]에서도 20-30대 교사의 심리적 소진이 높았으나, 통계적으로 유의하지 않았다. 이는 직업에 대한 열정이 넘치는 20-30대 교원들이 조직에서 요구하는 규칙에 따라 행동하면서 본인의 열정에 부합하는 것들을 마음껏 수행할 수 없어서 일어나는 것이라 생각되며 이를 도와줄 수 있는 방법 모색이 필요하다.

한국어교원의 이직 의도는 시간당 보수에 따라 유의한 차이를 보였고, 사후검증 결과 ‘30,000원 이하' 집단이 ‘36,000-39,000원' 집단보다 이직 의도가 높았는데, 이는 시간당 
보수에 대한 불만족 및 스트레스에 기인한 결과라 생각된다. 한국어교원은 계약 기간이 만료되면 별다른 수입 없이 다른 일을 찾아야 하는데, 이런 과정의 반복은 경제적으로 여유가 있는 사람이 아니면 버텨내기가 어렵다[19]. 선행연구[14]에서도 이직 의도가 ‘있다’고 응답한 경우가 ‘없다’의 수보다 2 배 이상 많게 나타났는데, 직장을 그만두고 싶다는 의도가 있다는 자체만으로도 직무 안정을 저해하고, 한국어교육의 질을 낮추는 요소가 될 수 있다. 직무스트레스가 이직 의도에 가장 큰 영향을 미치는 요인으로 나타난 연구 결과는 직업은 다르지만 직무스트레스가 높을수록 이직 의도도 높아지는 것으로 나타난 선행연구[18][20]를 지지하는 결과이다. 직무스트레스는 직무만족도를 저하시켜 이직 의도를 증가시키므로 한국어교원의 이직 의도를 낮추기 위해서는 직무스트레스를 완화하기 위한 중재가 필요하다.

\section{5. 결론 및 제언}

본 연구는 국내 한국어교원을 대상으로 직무만족도, 직무스트레스, 감정노동, 심리적 소진이 이직 의도에 미치는 영향을 파악하기 위한 연구로 한국어교육 현장의 환경 개선을 위한 기초 자료를 제공하고자 시도되었다.

연구 결과, 대상자의 직무스트레스는 감정노동, 심리적 소진, 이직 의도와 순상관관계가 있었다. 이직 의도는 직무만족도와 역상관관계가 있었고, 직무스트레스, 심리적 소진과 순상관관계가 있었다. 대상자의 이직 의도에 가장 영향을 미치는 요인은 직무스트레스, 직무만족도, 연령순이었다. 특히, 한국어교의 직업 자체에 대한 만족도는 높았으나, 보상체계, 사회적 인식, 근무환경과 지원체계에 대한 직무만족도가 낮은 만큼 국가 차원의 제도적, 정책적 뒷받침이 필요하며 교육 현장에서는 고용 불안정과 낮은 급여, 복지 제도 등 한국어교원의 근무환경 개선과 정당한 대우가 시급하다.

본 연구 결과를 바탕으로 다음과 같은 제언을 하고자 한다. 첫째, 본 연구는 국내 한국어교원을 대상으로 진행된 연구로서 희망자에 한해 연구를 진행하였으므로 일반화에 제한점이 있으므로 추가 연구를 제언한다. 둘째, 한국어교원의 직무스트레스를 구체적이면서 깊게 이해하고 보다 실증적인 접근을 할 수 있는 추가 연구를 제언한다. 셋째, 대상자를 확대하여 한국어교원의 이직 의도에 영향을 미치는 요인을 확인하는 경로 분석 및 구조방정식 모형을 이용한 연구를 제언한다. 넷째, 한국어교원의 직무스트레스 감소 등을 위한 프로그램 개발과 그 효과를 확인하는 추가 연구를 제언한다.

\section{References}

[1] Status of issuance of Korean languages teacher certificates, National Institute of Korean Language, pp.1-13, (2021), http://kteacher.korean.go.kr/reference/13962

[2] S. M. Sim, A. R. Jung, A Study on Job Stress of KSL Teachers, Urimalgeul: The Korean Language and Literature, (2011), Vol.53, pp.137-173, UCI: G704-001206.2011.53..004

[3] S. Y. Lee, J. S. Lee, S. Y. Kim, J. Y. Lee, The Effect of Job Stress and Job Satisfaction on Professional Self-Concept in Nurses, Journal of Digital Convergence, (2017), Vol.15, No.9, pp.273-281, DOI: 10.14400/JDC.2017.15.9.273 
The Effects of Korean Language Teachers' Job Satisfaction, Job Stress, Emotional Labor, and Psychological Burnout on Turnover Intention

[4] B. M. Bang, S. Y. Lee, J. O. Cheong, Empirical study on the turn-over intention of university hospital nurses, Journal of Digital Convergence, (2015), Vol.13, No.2, pp.205-213, DOI: 10.14400/JDC.2015.13.2.205

[5] E. K. Kwon, The effect of job stress on job exhaustion on Middle School teacher, Journal of Digital Convergence, (2018), Vol.16, No.8, pp.81-87, DOI: 10.14400/JDC.2018.16.8.081

[6] R. Seok, A Study on the Relations between Teachers' Emotional Labor, Job Stress, and Burnout, Ewha Womans University, Master's Thesis, pp.1-75, (2014)

[7] S. J. Park, A Study on the Job Environment and Job Satisfaction of Korean Language Lectures, Culture and Convergence, (2018), Vol.40, No.8, pp.167-206.

[8] S. Vaezi, N. Fallah, The relationship between Self-efficacy and Stress among Iranian EFL Teachers, Journal of Language Teaching and Research, (2011), Vol.2, No.5, pp.1168-1174, DOI: 10.4304/jltr.2.5.1168-1174

[9] T. L. Weinstein, E. J. Trickett, The development of an instrument to measure English Language Learner (ELL) teacher work stress, Teaching and Teacher Education, (2016), Vol.55, No.1, pp.24-32, DOI: 10.1016/j.tate.2015.12.001

[10] M. T. Yazdi, K. Motallebzadeh, H. Ashraf, The Role of Teacher's Self-efficacy as a Predictor of Iranian EFL Teacher's Burnout, Journal of Language Teaching and Research, (2014), Vol.5, No.5, pp.1198-1204, DOI: 10.4304/jltr.5.5.11981204

[11] K. Acheson, J. Taylor, K. Luna, The Burnout Spiral: The Emotion Labor of Five Rural U.S. Foreign Language Teachers, The Modern Language Journal, (2016), Vol.100, No2, pp.522-537, DOI: 10.1111/modl.12333

[12] B. R. Kim, A Study on the job Stress Factors of KSL Teachers at a Language Institutions of Universities, Hankuk University, Master's Thesis, pp.1-98, (2020)

[13] E, H, Kim, The Study of Effect of Job Stress and Teacher Efficacy on Organizational Commitment in Korean Teachers: Based on Korean School for Korean American, Kyunghee Cyber University, Master's Thesis, pp.1-120, (2019)

[14] S. Y. Hwang, A Study on the Relationship between the Self-Efficacy and Job Satisfaction of Korean Education Leaders, Wonkwang University, Master's Thesis, pp.1-83, (2014)

[15] S. S. Kang, A Study on the Job Stress Factors of Korean Language Teachers in Online Classes - in Online Classes after COVID-19 -, Hansung language literature, (2021), Vol.44, pp.119-153.

[16] J. Y. Lim, The Effects of Teachers' Emotional Labor and Emotion Regulation on Job Stress, Burnout and Teacherefficacy, Sungkyunkwan University, Master's Thesis, pp.1-76, (2011)

[17] J. A. Kang, The Effects of Elementary School Homeroom Teachers' Burnout on Students' School Life A djustmentand A cademic Self-Efficacy, Hannam University, Master's Thesis, pp.1-66, (2010)

[18] E. M. Hwang, Factors Associated with Turnover Intention in Community Mental Health Professionals, Ewha Womans University, Master's Thesis, pp.1-70, (2015)

[19] K. S. Lee, A Study on Improving Educational Environment for Korean Language Instructor, Kyonggi University, Master's Thesis, pp.1-76, (2019)

[20] M. R. Park, S. Y. Bang, N. J. Je, The Effects of Nurses' Turnover Intention, Nunchi, and Job Stress on Organizational Socialization, Journal of Digital Convergence, (2020), Vol.18, No1, pp.159-168, DOI: 10.14400/JDC.2020.18.1.159 